\title{
COVID-19: the role of excessive cytokine release and potential ACE2 down-regulation in promoting hypercoagulable state associated with severe illness
}

\author{
Fenghe $\mathrm{Du}^{1,3} \cdot$ Bao Liu $^{1}$ (]) Shuyang Zhang ${ }^{2}$ \\ Published online: 16 July 2020 \\ (c) Springer Science+Business Media, LLC, part of Springer Nature 2020
}

\begin{abstract}
The novel coronavirus disease (COVID-19) has become a universally prevalent infectious disease. The causative virus of COVID-19 is severe acute respiratory syndrome coronavirus type 2. Recent retrospective clinical studies have established a significant association between the incidence of vascular thrombotic events and the severity of COVID-19. The enhancement in serum levels of markers that reflect a hypercoagulable state has been suggested to indicate a poor prognosis. Therefore, at present, it is crucial to understand the mechanisms that foster the hypercoagulable state in COVID-19. Over-activated inflammatory response, which is manifested as excessive cytokine release in COVID-19 patients, is also associated with COVID-19 severity. This review discusses the immuno-pathological basis of the excessive cytokine release in COVID-19. Besides, this article reviews the role of pro-inflammatory or anti-inflammatory cytokines, whose significant elevations in their serum levels have been consistently detected in multiple different clinical studies, in promoting the hypercoagulable state. Since the expression of angiotensin-converting enzyme 2 (ACE2) is potentially down-regulated in COVID-19, as proposed by a recent bio-informatic analysis, mechanisms through which reduced ACE2 expressions promote vascular thrombosis are summarized. In addition, the reciprocal-enhancing effects of the excessive cytokine release and the downregulated ACE2 expression on their pro-thrombotic activities are further discussed. Here, based on currently available evidence, we review the pathogenic mechanisms of the hypercoagulable state associated with severe cases of COVID-19 to give insights into prevention and treatment of the vascular thrombotic events in COVID-19.
\end{abstract}

Bao Liu

liubao72@aliyun.com

Shuyang Zhang

shuyangzhang103@nrdrs.org

1 Department of Vascular Surgery, Peking Union Medical College Hospital, Chinese Academy of Medical Sciences, Shuaifuyuan 1st, Dongcheng District, Beijing 100730, China

2 Department of Cardiology, Peking Union Medical College Hospital, Chinese Academy of Medical Sciences, Shuaifuyuan 1st, Dongcheng District, Beijing 100730, China

3 Four-Year Program of Clinical Medicine, Peking Union Medical College Hospital, Peking Union Medical College, Chinese Academy of Medical Sciences, Beijing, China 


\section{Graphic abstract}

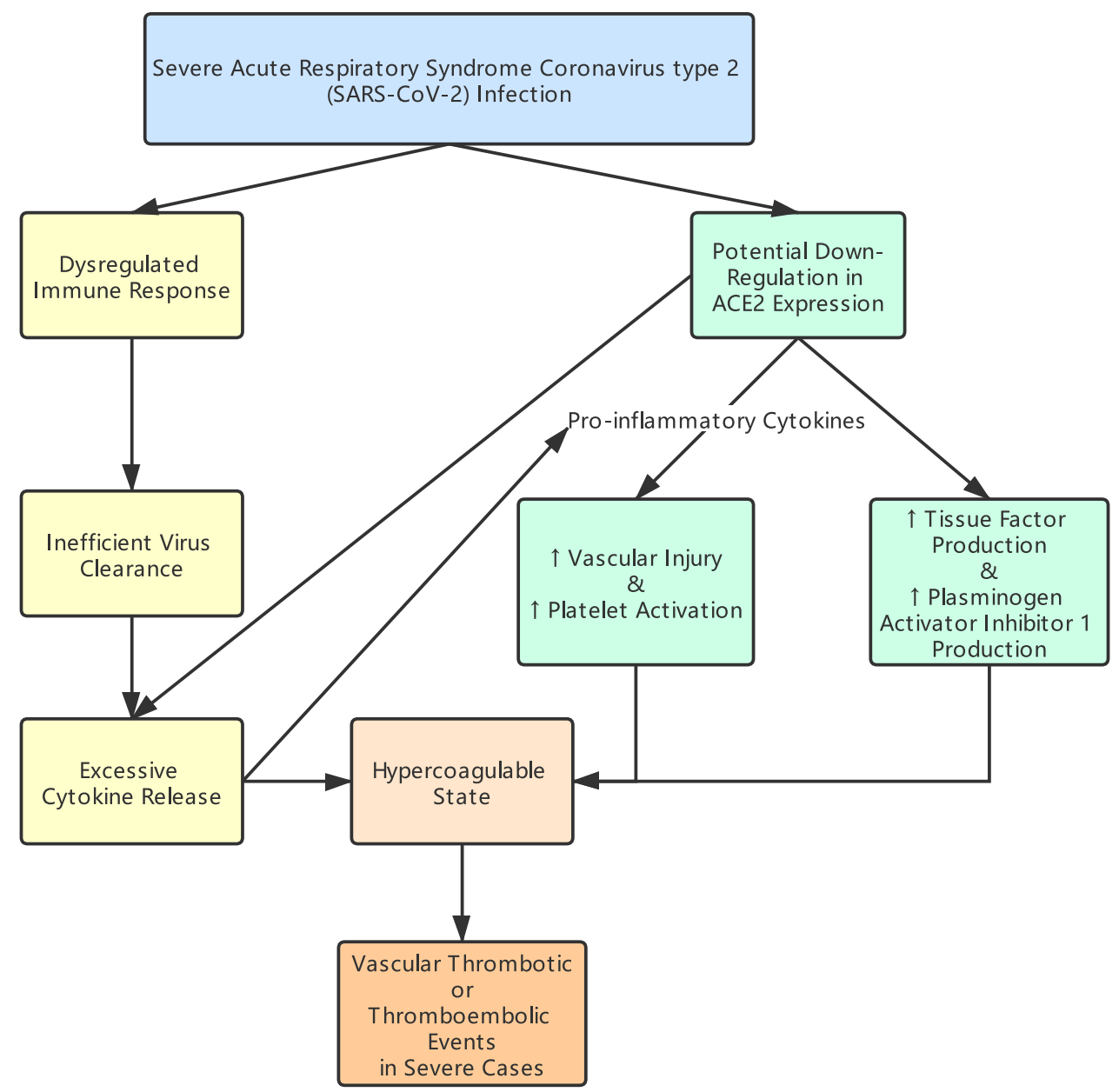

Keywords COVID-19 Excessive cytokine release $\cdot$ ACE2 $\cdot$ Hypercoagulable state $\cdot$ Vascular thrombotic events

\section{Highlights}

- Dysregulated immune responses in COVID-19 could lead to inefficient virus clearance, which further brings about over-activated inflammatory response and excessive cytokine release.

- Excessive cytokine release in severe cases of COVID19 is characterized by enhanced serum levels of IL-2, IL-6, IL-10, and IFN- $\gamma$. Increased serum level of the anti-inflammatory cytokine IL-10 might be a compensatory mechanism to reduce the over-activated inflammatory response.

- ACE2 expression levels could be down-regulated, according to the recent bio-informatic analysis with the interactome model based on characteristics of human protein/SARS-CoV interactions, but a direct experimental evidence is still required to confirm this prediction.

- In severe COVID-19, the excessive cytokine release and potential down-regulation in ACE2 expressions can not only promote a hypercoagulable state individually, but also reciprocally enhance the pro-thrombotic functions of each other.

- Anti-inflammatory therapies, including tocilizumab, chloroquine, and hydroxychloroquine, which can be promising treatment to control excessive cytokine release in severe COVID-19, have the potential to reduce the risk of vascular thrombotic events, but more clinical data are needed for optimum instruction of drug use and drug selection. 


\section{Introduction}

The novel coronavirus disease (COVID-19), caused by severe acute respiratory syndrome coronavirus type 2 (SARS-CoV-2) infection, is currently leading to a global pandemic. Clinical studies so far have demonstrated an association between COVID-19 severity and vascular thrombotic or thromboembolic events [1]. Moreover, COVID-19 severity is also frequently associated with over-activated inflammatory response characterized by excessive cytokine release [2-6]. To prevent the vascular thrombotic events in severe COVID-19, it is urgently necessary to understand the underlying pathogenic mechanisms.

Based on currently available evidence, we discuss the mechanisms of initiation, the characteristics, and the immuno-pathological basis of the over-activated inflammatory response associated with severe COVID-19. Furthermore, we summarize cytokines that have consistently displayed enhanced serum levels in severe patients. Mechanisms through which these cytokines influence the coagulable state are reviewed in detail after an overview of the role of excessive pro-inflammatory cytokine release in promoting hypercoagulable state in COVID-19. Additionally, we discuss the mechanisms and potential of anti-inflammatory medications investigated in recent clinical trials to prevent the hypercoagulable state in severe COVID-19.

Despite a lack of direct evidence showing a downregulation of angiotensin-converting enzyme 2 (ACE2) expression levels in COVID-19, a recent bio-informatic analysis predicts a downregulated ACE2 expression in SARS-CoV-2 infection [7]. By interpreting the antithrombotic and anti-inflammatory functions of ACE2, we propose that the potential ACE2 down-regulation in COVID-19 can contribute to the pathogenesis of hypercoagulable state and excessive inflammation in severe cases. Moreover, we further discuss the mutually promoting effects of excessive cytokine release and potential ACE2 down-regulation on the pro-thrombotic activities of each other. Ultimately, based on previous preclinical studies and recent clinical studies, we analyze the effects of angiotensin-converting enzyme inhibitors (ACEIs) and angiotensin II receptor blockers (ARBs) treatment on the risk of vascular thrombosis.

By interpreting the pathological mechanisms, we aim to illustrate that excessive pro-inflammatory cytokine release and potential ACE2 down-regulation can promote the hypercoagulable state in severe COVID-19, and propose that the anti-inflammatory medications, as well as ACEI/ARB, can benefit severe COVID-19 patients by reducing the risk of vascular thrombotic events.
Association between disease severity and hypercoagulable state in COVID-19

Although pneumonia is the most common manifestation of severe COVID-19, recent clinical studies have suggested a significant association between vascular thrombotic or thromboembolic events and COVID-19 severity $[1,2,8]$. In a retrospective analysis of 183 COVID-19 patients, a marked increase in serum D-dimer level, indicating a hypercoagulable state, is frequently observed in non-survivors. Disseminated intravascular coagulation (DIC) has occurred in $71.4 \%$ of non-survivors, compared to an only $0.6 \%$ chance of DIC in patients who survived [1]. Additionally, a pooled analysis has further confirmed the association between increased serum D-dimer level and poor clinical prognosis [9].

In a recent COVID-19 clinical case report, anti-phospholipid antibodies (aPL) have been detected in 3 ICU patients with multiple infarcts, and anti-phospholipid syndrome (APS) is suspected to be a potential cause of the vascular thrombotic events in these severe cases [10]. As evidenced by previous clinical studies, persistent positive for serum aPL is not necessarily related to the clinical characteristics of APS, including thrombotic events, in patients with virus infection [11]. In addition to the increased aPL, a second thrombophilic factor is necessary for the thrombotic events associated with APS to occur [12]. Therefore, a hypercoagulable state might be an essential factor that synergistically contributes to the observed multiple infarctions along with the enhanced serum aPL in the 3 ICU patients with COVID-19.

The hypercoagulable state, manifested by the multiinfarctions and the increased serum level of D-dimer, is related to COVID-19 severity and indicate a poor prognosis. Understanding the pathophysiology behind the vascular thrombotic events in severe COVID-19 is beneficial for the prevention and treatment of these events.

\section{Dysregulated T cell immune response can lead to ineffective clearance of SARS-CoV-2 and initiation of over-activated inflammatory response in COVID-19}

A retrospective clinical study indicates that, compared to mild COVID-19 patients, severe patients display lower levels of CD4 $+\mathrm{T}$ cells and CD8 $+\mathrm{T}$ cells, as well as higher levels of interleukin-6 (IL-6) and interleukin-10 (IL-10) in the peripheral blood before receiving any treatment for the disease. No significant difference is found in the T cellpolarizing cytokines, including interleukin-17 (IL-17), interferon $\gamma$ (IFN- $\gamma$ ), and interleukin-4 (IL-4), responsible for the polarization of T helper cell (Th) 17, Th1, and Th2, respectively [3]. However, compared to healthy individuals, COVID-19 patients have displayed elevation of serum levels 
of cytokines that are suggestive of pro-inflammatory Th1 activation, including IFN- $\gamma$ and IFN- $\gamma$ inducible protein 10 (IP-10). Besides the enhanced levels of pro-inflammatory cytokines, increased plasma levels of anti-inflammatory cytokines, including IL-10, have been simultaneously detected in COVID-19 patients, suggesting a dysregulation of the adaptive immune system following the virus infection [2]. Although the mechanism underlying the dysregulated immune response in COVID-19 is by far beyond comprehension, clinical studies have shown that, both declined levels of innate and adaptive lymphoid cell, and an increase in the percentage of naïve $\mathrm{CD} 4+\mathrm{T}$ cells accompanied by a reduction in the percentage of memory CD4+ cells, are associated with SARS-CoV-2 infection, indicating a reduced efficacy for virus clearance in infected patients [13, 14].

Thus, dysregulated $\mathrm{T}$ cell immune responses are observed in COVID-19, potentially contributing to the commonly seen lymphocytopenia in infected patients, leading to inefficient clearance of the virus $[2,15]$. Previous animal experiments using mouse models with MERS (Middle East respiratory syndrome) and SARS-CoV (severe acute respiratory syndrome coronavirus) infections have shown that the timing of immune response in the virus infections is critical for optimal virus clearance: an early anti-viral response before the peak of virus replication after an infection is important for the inhibition of virus replication and the activation of anti-viral adaptive immune responses; however, a delayed immune response to the virus infection not only inhibits the virus specific adaptive immune responses, but also enhances the excessive inflammatory cytokine release and the leukocyte infiltrations into tissues or organs, leading to a poor disease outcome $[16,17]$. Therefore, ineffective clearance of SARS-CoV2 following its infection can lead to a delayed immune response, which can bring about continuous inflammations and excessive cytokine release.

\section{Characteristics of serum cytokine profile in severe COVID-19 patients with excessive cytokine release}

According to the result of a retrospective clinical study, excessive cytokine release has occurred in severe patients with COVID-19. Among COVID-19 patients, intensive care unit (ICU) patients $(n=13)$ have higher serum levels of interleukin-2 (IL-2), interleukin-7 (IL-7), IL-10, granulocytecolony stimulating factor (G-CSF), IP-10, monocyte chemoattractant protein-1 (MCP-1), macrophage inflammatory protein 1- $\alpha$ (MIP-1 $\alpha$ ), and tumor necrosis factor- $\alpha$ (TNF$\alpha)$ than non-ICU patients $(n=28)$. Compared to healthy adults, both ICU and non-ICU patients have shown enhanced serum levels of interleukin-1 $\beta$ (IL-1 $\beta$ ), interleukin-1 receptor antagonist (IL-1RA), IL-7, interleukin-8 (IL-8), interleukin-9 (IL-9), interleukin-10 (IL-10), basic fibroblast growth factor (FGF2), G-CSF, granulocyte-macrophage colony-stimulating factor (GM-CSF), IFN- $\gamma$, IP-10, MCP1$, MIP- $1 \alpha$, macrophage inflammatory protein $1-\beta$ (MIP- $1 \beta)$, platelet-derived growth factor (PDGF), TNF- $\alpha$, and vascular endothelial growth factor (VEGF) [2]. Besides, Yang et al. have revealed a positive correlation between the levels of IP-10, monocyte chemoattractant protein-3 (MCP-3), IL1RA in the peripheral blood, and the severity of the coronavirus infection based on the Murray score [4].

Serum cytokine profiles, including those of IL-2, IL-4, IL-6, IL-10, IFN- $\gamma$, and TNF- $\alpha$, change dynamically after the disease onset in severe patients, reaching their peak levels in 4 to 6 days after the disease onset [5]. After the disease onset, while mild patients have not had remarkable fluctuations in the serum levels of any of these cytokines, significant fluctuations in IL- 2 and IFN- $\gamma$ serum levels have been discovered in severe patients. In severe patients, IL-2 and IFN- $\gamma$ serum levels have declined to the initial level in 7-9 days after the disease onset. The serum level of IL-6 has remained continuously higher in severe patients than in mild patients, and the serum level of IL-10 has remained higher in severe patients than in mild patients by the end of 13-15 days after the disease onset. However, no significant difference in serum levels of IL- 4 and TNF- $\alpha$ between mild and severe patients has been detected throughout the whole course of the disease [5].

\section{Immuno-pathological basis of over-activated inflammatory response and excessive cytokine release in severe COVID-19}

A report by Zhou et al. reveals the immuno-pathological basis behind the hyper-inflammatory immune response associated with severe COVID-19. By intracellular staining of potential cytokines responsible for promoting cytokine storm in SARS and MERS, Zhou et al. have demonstrated that compared to healthy individuals, ICU and non-ICU patients have increased expressions of IL- 6 and GM-CSF in the $\mathrm{CD} 4+\mathrm{T}$ cells. Moreover, the extent of the increment in IL-6 and GM-CSF expressions in CD4 + T cells is correlated with the severity of disease manifestations (Fig. 1). Th1 cells, positively stained for both GM-CSF and IFN$\gamma$, are only present in ICU patients, but not in non-ICU patients. This phenomenon, in part, explains the over-activated inflammation in severe patients with COVID-19 [6]. Enhanced plasma levels of activated CD14+CD16 + monocytes capable of producing pro-inflammatory cytokines IL-6 and GM-CSF are found only in COVID-19 patients, but not in healthy individuals [6].

Acting on the GM-CSF receptors on myeloid cells, GM-CSF leads to activation of the Janus kinase2- signal transducer and activator of transcription5 (JAK2-STAT5) pathway, influencing both the differentiation of myeloid precursor cells and the polarization of macrophages [18]. 
Fig. 1 Schematic diagram showing the immuno-pathological basis of excessive cytokine release in severe COVID-19 patients. SARS-CoV-2 severe acute respiratory syndrome coronavirus type 2, IL-6 interleukin-6, GM-CSF granulocytemacrophage colony-stimulating factor, $I F N-\gamma$ interferon $\gamma$, GMP granulocyte-macrophage progenitor, SOCS3 suppressor of cytokine signaling $3, G-C S F$ granulocyte-colony stimulating factor, $I R F-8$ interferon responsive factor 8

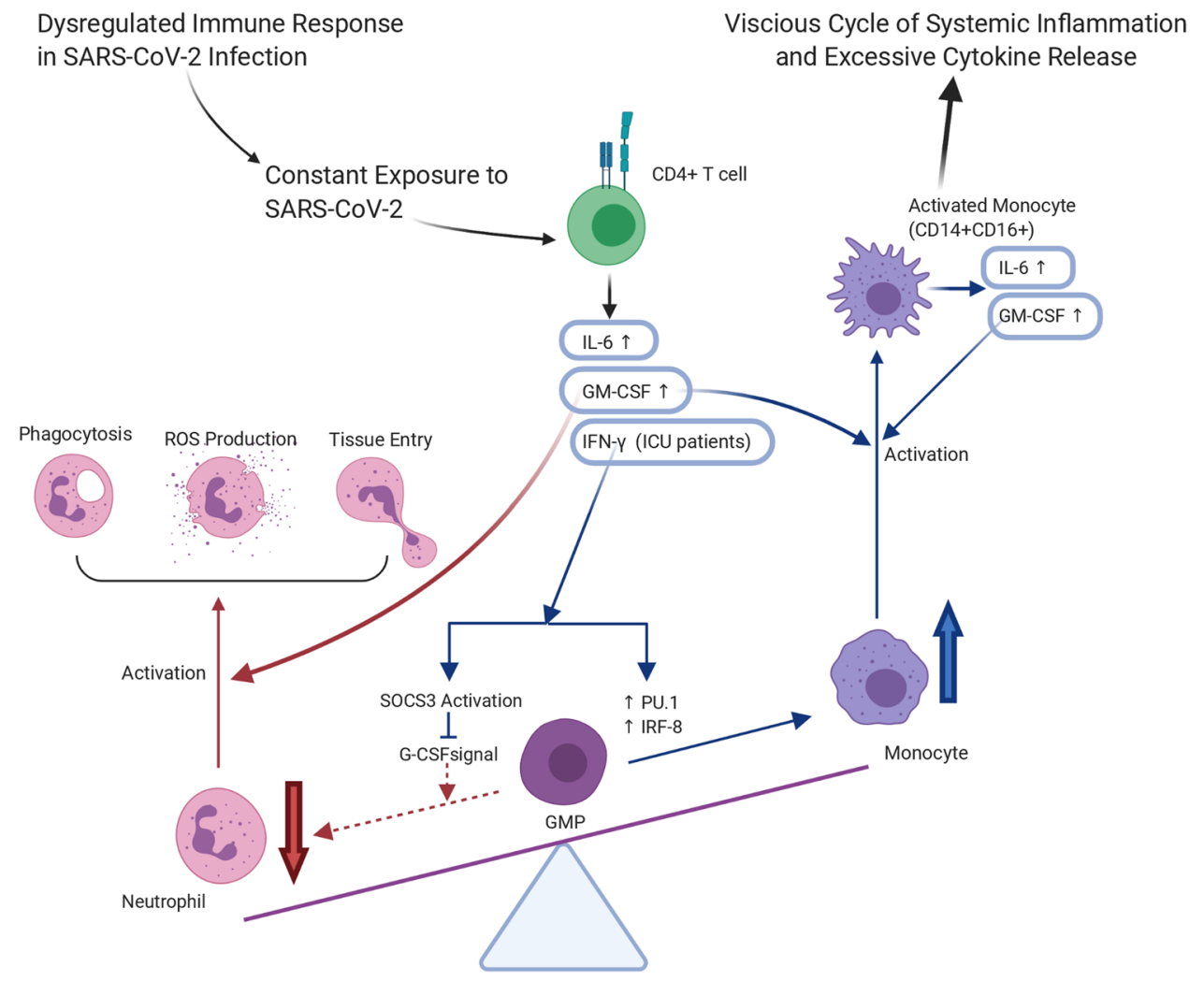

Although the activity of GM-CSF is redundant in physiological myeloid hematopoiesis because of the presence of G-CSF and macrophage-colony stimulating factor (M-CSF), GM-CSF is responsible for emergent hematopoiesis in acute pathological conditions such as acute infections, in accordance with the sudden increment of its serum level following an acute infection [19]. In COVID-19, enhanced GM-CSF level can increase the GM-CSF receptor signal strength in myeloid cells, promoting their differentiation into proinflammatory macrophage subtype [19]. An in vivo study suggests that GM-CSF dependent PU.1 expression mediates the terminal differentiation of macrophages and the enhancement in phagocytic activities of macrophages [20]. Besides the role of GM-CSF in regulating macrophage differentiation and function, GM-CSF can also up-regulate the immunological activities of neutrophils, including tissue entries, phagocytic activities, and reactive oxygen species (ROS) productions (Fig. 1) [21].

During virus infections, activated $\mathrm{T}$ cells can enter the bone marrow and influence hematopoiesis by secreting IFN- $\gamma[22,23]$. Both in vitro and in vivo evidence has shown that T-cell-derived IFN- $\gamma$ favors monocyte differentiation over neutrophil differentiation during myelopoiesis in the bone marrow. This tilted balance of myeloid progenitor development away from neutrophil towards monocyte is mediated by both IFN- $\gamma$-stimulated expressions of PU.1 and interferon responsive factor 8 (IRF-8), which are inducers of monocyte differentiation, and IFN- $\gamma$-induced activation of suppressor of cytokine signaling 3 (SOCS3), which inhibits the phosphorylation of STAT3 in response to G-CSF, in granulocyte-macrophage progenitors (Fig. 1) [24]. IFN- $\gamma$ can also skew the development of multipotent hematopoietic progenitors to the monocytic lineage in an indirect manner by stimulating IL- 6 production in the bone marrow mesenchymal stem cells [25]. Moreover, in response to IFN- $\gamma$, the production of IL- 6 in macrophages is also positively regulated through direct IL-6 promoter binding by Notch1 [26].

When encountering the novel coronavirus, the immune system displays low efficacy for virus clearance [13, 14]. Constantly exposed to the viral pathogen, the immune system may initiate a continuous systemic inflammation through GM-CSF and IFN- $\gamma$ production by T cells. GM-CSF and IFN- $\gamma$ could promote both the function and the production of macrophages. Activated macrophages could further continue the vicious cycle of excessive systemic inflammation by promoting the production and immunological activities of itself through GM-CSF secretion (Fig. 1) [6]. The excessive inflammatory response in severe patients, potentially attributed to unresolved virus infection, could eventually result in $\mathrm{T}$ cell depletion. In accordance, a high neutrophil to CD8+ T cell ratio (N8R) in the blood has been suggested to predict a worse prognosis in COVID-19 patients [5]. This observation might be explained by the $\mathrm{T}$ cell depletion in severe patients, in conjunction with the role of IFN- $\gamma$, secreted by $\mathrm{T}$ 
cells, in favoring monocytes differentiation versus neutrophil differentiation in the bone marrow during virus infections.

Age and human leucocyte antigen (HLA) polymorphisms can be factors that predispose COVID-19 patients to prolonged and excessive inflammations. An aged immune system is not only associated with a decreased efficiency for virus clearance due to declined $\mathrm{B}$ and $\mathrm{T}$ cell productions and functions, leading to constant viral exposure and excessive inflammations, but also associated with an increased propensity for excessive pro-inflammatory cytokine release because of reduced productions of the immunosuppressive thymusderived regulatory T cells (Tregs) [27, 28]. Additionally, HLA displays extensive polymorphisms, and is crucial for the immune response to viral antigens. SARS-CoV-2 infection may be similar to other types of virus infection, where associations can exist between certain HLA haplotypes and disease severity [29]. Certain HLA haplotypes might predispose COVID-19 patients to a more excessive inflammatory response. Future genetic sequencing studies are required to understand this association, which can guide the treatment and management of patients in the clinic, as well as vaccine productions.

Early anti-viral immune responses can facilitate the clearance of pathogens; however, the prolonged and excessive inflammatory activities, observed in severe COVID-19 patients, can result in tissue damage and hypercoagulable state.

\section{Contribution of excessive cytokine release to hypercoagulable state in severe COVID-19 patients}

Differences in standards for severe illness and variations in health conditions among patients may lead to discrepancies of the results from different retrospective clinical studies that compare serum levels of cytokines between mild and severe COVID-19 patients. However, most retrospective clinical studies so far have consistently displayed enhanced serum levels of pro-inflammatory cytokines, including IL-2, Th1related IFN- $\gamma$, IL-6 along with increased serum levels of the anti-inflammatory cytokine IL-10 in severe patients, in comparison with the serum levels of these cytokines in mild patients [2-6]. Based on previous experimental and clinical evidence, generally, the pro-inflammatory cytokines, including IL-2, IFN- $\gamma$, IL-6, can promote a hypercoagulable state in favor of thrombus formation, whereas the anti-inflammatory cytokine, IL-10, conducts anti-coagulative activities which prevent vascular thrombotic events (Fig. 2).

In severe COVID-19, the excessive pro-inflammatory cytokine release can contribute to the activation of coagulation cascade. Thrombin, an essential candidate in the coagulation cascade, not only mediates the blood clot formation by converting fibrinogen to fibrin, but also can act on the proteinase-activated receptors to amplify the inflammation in a positive feedback manner [30]. The presence of positive regulations between inflammation and coagulation may explain the concurrent existence of excessive pro-inflammatory cytokine release and serum markers of hypercoagulable state in severe COVID-19 patients.

Although the excessive pro-inflammatory cytokine release in severe COVID-19 patients can promote vascular thrombosis through complicated interplays with factors that participate in the blood coagulation, it might not be the only etiology of hypercoagulable state and vascular thrombus formation in severe COVID-19. A recent autopsy study has demonstrated that SARS-CoV-2 can directly invade and damage vascular endothelial cell (EC), as evidenced by the presence of viral inclusions inside the vascular ECs in the histological analyses [31]. Besides, aggregation of inflammatory leukocytes around vascular ECs has also been detected in the histological analyses, indicating that SARS-CoV-2 can possibly induce vascular endothelitis by directly invading ECs, facilitating vascular thrombosis [31]. Therefore, the significance of excessive pro-inflammatory cytokine release as an etiology of hypercoagulable state and thrombus formation in severe COVID-19 should be further assessed in future experimental studies.

According to the previously described characteristics of the dynamically changing cytokine profiles, in severe COVID-19 patients, enhanced IL-2 and IFN- $\gamma$ serum levels persist only for the first 7-9 days following disease onset, whereas the IL-6 serum level is continuously elevated throughout the whole course of the disease [5]. Hence, in severe COVID-19, enhanced serum levels of IL-2 and IFN- $\gamma$ could be a trigger for the elevation in serum IL-6 level by increasing macrophage differentiation and activation (Fig. 1). The mechanisms by which the pro-inflammatory cytokines, IL-2, IFN- $\gamma$, IL-6, and the anti-inflammatory cytokine, IL-10, affect the coagulable state are interpreted in detail subsequently. The order of discussion on the proinflammatory cytokines is arranged based on the potential course of sequence by which their release is triggered during the over-activated inflammatory response associated with severe COVID-19.

The excessive release of IL-2, IFN- $\gamma$, IL-6, and IL-10 in severe COVID-19 could result from the SARS-CoV-2 infection itself, the bacterial infection secondary to the SARS$\mathrm{CoV}-2$ infection in immune-compromised individuals, or the excessive innate immune response to damage-associated molecular patterns (DAMP) produced by tissue damages due to SARS-CoV-2 invasion [2, 4]. Hence, blocking the host cell entry and the replication of SARS-CoV-2 during early infection could prevent the excessive release of the pro-thrombotic cytokines in COVID-19. However, for severe patients who have already developed excessive inflammatory response, antagonizing the productions and activities 


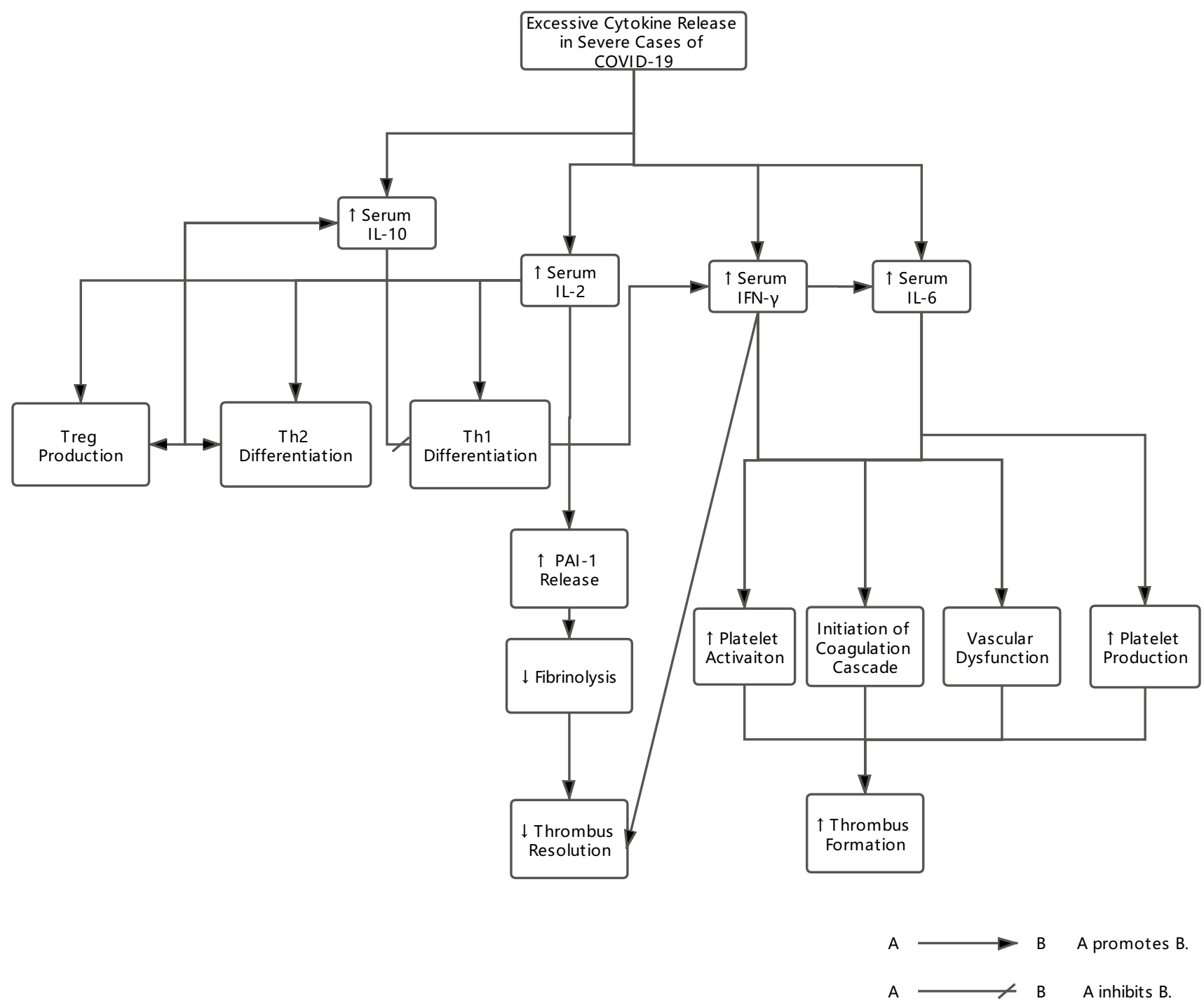

Fig. 2 Schematic diagram summarizing the mechanisms through which main pro-inflammatory and anti-inflammatory cytokines in the over-activated immune responses associated with severe COVID-19 influence vascular thrombus formation and resolution. $I L-10$ interleu-

of the pro-thrombotic cytokines could be a better approach to attenuate the over-activated inflammatory response and to reduce the risk of vascular thrombosis.

\section{Cytokines with pro-thrombotic activities}

IL-2 IL-2 is pleiotropic regarding its influence on the differentiation of various CD4 $+\mathrm{T}$ cell subsets. IL-2 induces Th1 and Th2 differentiation by enhancing interleukin-12 (IL-12) receptor expression and IL-4 receptor expression, respectively, through STAT5 [32, 33]. However, IL-2 plays an inhibitory role in the differentiation of Th17 [32]. Additionally, IL-2 has been shown to increase the thymic or kin-10, $I L-2$ interleukin-2, $I F N-\gamma$ interferon $\gamma, I L-6$ interleukin-6, Treg regulatory T cell, Th1 T helper cell type 1, Th2 T helper cell type 2, $P A I-1$ plasminogen activator inhibitor-1

peripheral production of Tregs and the immuno-suppressive activity of Tregs [34, 35].

IL-2 can stimulate endothelial plasminogen activator inhibitor (PAI-1) release in vitro, indicating a potential for IL-2 to inhibit fibrinolysis [36]. Results of clinical study have shown that IL-2 can activate both coagulation and fibrinolysis in vivo, possibly mediated by IL-2 induced cytokines that can impair the anti-coagulant function of the vascular endothelium [37].

By initiating the differentiation of Th1, IL-2 can induce the production of IFN- $\gamma$ in T cell subsets [32, 38]. IFN- $\gamma$ is associated with pro-coagulant effects by several mechanisms introduced below. 
IFN- $\gamma$ IFN- $\gamma$ plays a dual role in vascular thrombosis by promoting thrombus formation, while delaying thrombus resolution. According to previous experimental evidence, IFN- $\gamma$ promotes thrombus formation mainly through increasing the platelet activities and impairing the vascular endothelium.

In vitro experiment on monocytic U937 cell in the condition of a low thrombin concentration has shown that IFN- $\gamma$ increases platelet adhesion to the monocytic cell, thereby promoting platelet activation, which is indicated by enhanced platelet 5-hydroxytryptamine (5-HT) release [39]. Furthermore, in vitro evidence has also indicated that Th1related activities, especially IFN- $\gamma$ secretion, increase the expression of tissue factor (TF) in monocytes, facilitating the pro-coagulant activity of monocytes [40].

IFN- $\gamma$ plays a crucial role in inflammation by mediating macrophage activation and leukocyte recruitment. Results of animal studies suggest that increased IFN- $\gamma$ production mediates monocyte activation and monocyte recruitment to the vessel, promoting vascular inflammation, ROS production, together with vascular EC and vascular smooth muscle cell (SMC) dysfunction [41]. In physiologic conditions, vascular ECs maintain their anti-thrombotic, anti-inflammatory, and vasodilative properties by producing substances, including anti-thrombin, thrombomodulin, prostaglandins, and nitric oxide (NO) [42]. IFN- $\gamma$ induces vascular dysfunction by promoting the expression of chemoattractant molecule MCP-1, changing the physiologic anti-inflammatory phenotype of the vascular ECs into the pathological pro-inflammatory phenotype, thereby leading to enhanced ROS production and decreased vasodilative function of the vascular endothelium, in favor of thrombus formation [43]. Damage of vascular ECs exposes the sub-endothelial pro-thrombotic matrix to the circulating platelets. Interactions between subendothelial pro-thrombotic proteins and platelets result in platelet adhesion, activation, and aggregation through complex receptor-mediated signalings [44, 45]. Additionally, a recent animal experiment shows that IFN- $\gamma$ can promote deep venous thrombosis by mediating neutrophil extracellular traps (NETs) formation [46].

After thrombus formation, IFN- $\gamma$ could impede the thrombus resolution through decreased VEGF and matrix metalloproteinase 9 (Mmp9) expressions in macrophages mediated by IFN- $\gamma$ /STAT1 signal pathway activation [47].

IL-6 Overall, IL-6 contributes to a hypercoagulable state by enhancing the activity and production of platelets, promoting an imbalance between plasma levels of coagulative factors and anti-coagulative factors, and inducing endothelial dysfunction.

IL-6 induces thrombus formation by increasing platelet production and activity. IL- 6 has been shown to promote a hypercoagulable state and accelerate blood clot formation via whole blood thromboelastography, as evidenced by the markedly reduced time before maximum velocity of clot growth (TMRTG). The IL-6-induced hypercoagulable state in the whole blood has been further confirmed by the hyper-activation of platelets under scanning electron microscopy [48]. IL-6 contributes to inflammatory thrombocytosis by up-regulating thrombopoietin (TPO) production in hepatocytes, indicated by in vivo experiments involving IL-6 administration and TPO neutralization in C57BL/10 mice [49]. Increased platelet production plays a role in promoting primary hemostasis during inflammation.

Furthermore, IL-6 can promote hypercoagulability by modulating plasma levels of coagulant factors. In vitro evidence has suggested that, in ECs and monocytes, IL-6 increases the expression of $\mathrm{TF}$, which initiates the activation of extrinsic coagulation pathway that is responsible for thrombus formation [50, 51]. Results of animal experiments also confirm the capability of IL-6 to stimulate the initiation of coagulation. In response to an Escherichia coli $(E$ coli.) endotoxin injection, an increase in plasma levels of thrombin fragments F1 F2 and thrombin-antithrombin III complexes, indicating coagulation activation, is abrogated by a simultaneous IL- 6 antibody injection in chimpanzees [52]. In canine, following IL-6 injection, plasma levels of fibrinogen and von Willebrand factor (vWf) are increased, while the plasma concentration of free protein $\mathrm{S}$ is reduced, suggesting that increasing the plasma level of IL-6 can induce a hypercoagulable state [53].

Last but not least, IL-6 signaling in ECs results in endothelial dysfunction, increasing the risk of vascular thrombotic events. Although ECs do not have IL-6 receptor expression, they do have the expression of glycoprotein 130 (Gp130), which can bind to the complex of IL-6 and its soluble receptor sIL-6R in the plasma, allowing ECs to respond to IL-6 stimulation [54]. IL-6 trans-signaling can activate vascular ECs by increasing the expressions of chemokines and cell adhesion molecules, as well as the secretion of IL- 6 by the vascular ECs, turning the physiologic phenotype of the vascular ECs into the pathologic phenotype [54]. Additionally, in a cell culture experiment, IL-6 trans-signaling in microvascular ECs leads to endothelial damages by promoting apoptosis [55].

Despite plenty of evidence showing the contribution of IL-6 to increased blood coagulability and thrombus formation, IL-6 could also be necessary for venous thrombus resolution by recruiting macrophages and enhancing expressions of Mmp2, Mmp9, and urokinase-type plasminogen activator (Plau) through IL-6/STAT3 signaling in macrophages [56]. However, the exact role IL-6 plays in thrombus resolution can be controversial because of the in vitro evidence showing up-regulated PAI-1 expression in adipose tissue by IL-6 [57]. 


\section{Cytokine with anti-thrombotic activities}

IL-10 The role and mechanism of IL-10 production during acute virus infection were elegantly reviewed by José M. Rojas et al. [58]. By mediating negative regulation of MHC II expression on antigen-presenting cells, IL-10 can impair the priming of Th1, which plays a vital role in controlling virus infections by facilitating the effector functions of cytotoxic leukocytes and lymphocytes [58, 59]. Although it is unclear whether the elevation of serum IL-10 in COVID-19 patients is a mechanism by which SARS-COV-2 circumvent the surveillance of adaptive immunity, IL-10 enhancement in severe cases is likely a compensatory mechanism to quench the over-activated inflammation, having an inhibitory effect on coagulation and thrombus formation.

Because of the anti-inflammatory function of IL-10, it could prevent vascular thrombosis by alleviating the pro-thrombotic effects associated with pro-inflammatory cytokines $[40,58]$. By inhibiting the production of proinflammatory cytokines, IL-10 can indirectly decrease mitochondrial ROS production in ECs, reducing the acute vascular endothelial cell activation [60]. IL-10 is elevated in response to venous thrombosis in the vascular wall, playing a role in suppressing vascular inflammation and reducing venous thrombosis, as evidenced by animal experiments in rats [61]. In a double-blinded cohort study involving 12 healthy volunteers, IL-10 injection has resulted in decreased bone marrow platelet production compared to placebo, therefore reducing the risk of thrombus formation [62]. A clinical study has further revealed the association between decreased serum IL-10 and endothelial dysfunction in patients with venous thrombosis [63].

\section{Potential of anti-inflammatory therapy to reduce the risk of vascular thrombosis in severe COVID-19}

By targeting the excessively released pro-thrombotic cytokines in severe COVID-19, anti-inflammatory therapy can theoretically alleviate the hypercoagulable state. Currently, it is believed that the timing of anti-inflammatory therapy is an essential factor to be considered when weighing the risks and benefits for COVID-19 patients. During the incubation period and the non-severe symptomatic stage of COVID-19, anti-inflammatory therapy can impair the antiviral immune response, increasing the risk of aggravating disease severity; however, anti-inflammatory therapy in the severe stage of COVID-19, when the viral load is high and the optimal time window for virus clearance is missed, can benefit COVID-19 patients by alleviating tissue damages due to the excessively activated inflammatory response [64]. The use of anti-inflammatory medications, including tocilizumab, as well as chloroquine and hydroxycloroquine, to suppress the over-activated inflammatory response in severe
COVID-19 has been undergoing clinical investigations. By antagonizing the cytokines with pro-thrombotic effects, these anti-inflammatory medications also have the potential to lower the risk of vascular thrombosis.

\section{Tocilizumab}

Conventionally, corticosteroids are used as a treatment for excessive inflammation, but high doses and long durations of drug intake are often needed, usually leading to serious side effects $[65,66]$. IL-6 is considered as a key mediator of excessive pro-inflammatory cytokine release in COVID-19, and tocilizumab, an anti-IL-6 receptor monoclonal antibody, is used to suppress the over-activated inflammatory response in severe COVID-19 cases in several recent observational clinical studies. These studies indicate that tocilizumab, without significant associated adverse effect, is effective for controlling excessive inflammations and reducing disease mortality in severe COVID-19 patients, especially for those with significant elevation in serum IL-6 level [66, 67]. Besides, a systemic review also indicates that tocilizumab could be a promising treatment for the excessive inflammation in severe COVID-19 [68]. However, considering the number of patients participated in these studies are relatively small, and these studies are merely observational, the conclusions of these studies need to be confirmed by randomized controlled clinical trials with larger numbers of participants.

By suppressing the over-activated inflammation, tocilizumab can theoretically mitigate vascular thrombosis by reducing the pro-thrombotic effects of the pro-inflammatory cytokines during excessive inflammations in severe COVID19 (Fig. 2). Hence, future clinical studies of tocilizumab could evaluate the potential of tocilizumab to reduce vascular thrombotic events by adding vascular thrombotic complications, including DIC, as a secondary endpoint.

\section{Chloroquine and hydroxychloroquine}

According to recent clinical studies, low dosage of adjunctive chloroquine and hydroxychloroquine treatment could be an effective solution for excessive pro-inflammatory cytokine release in severe COVID-19 patients. In a retrospective observational study with 550 patients, in addition to the basic treatments for COVID-19, low doses of hydroxychloroquine significantly reduce the fatality and the serum level of pro-inflammatory IL-6 in severe COVID-19 patients [69]. A randomized controlled clinical trial suggests that compared to a low dosage of chloroquine treatment, a high dosage of chloroquine treatment for severe COVID-19 patients is associated with increased incidences of adverse effects, especially when used adjunctively with other antibiotics or anti-viral medications [70]. However, severe 
COVID-19 patients in the group receiving high dosage of chloroquine treatment are of older ages, which could be a confounding factor in this randomized clinical trial.

Chloroquine and hydroxychloroquine, which can be promising in the treatment of excessive inflammatory response in severe COVID-19, have both immuno-modulatory and anti-thrombotic functions. Chloroquine and hydroxychloroquine can inhibit the production of IFN- $\gamma$, IL-6, and TNF- $\alpha$ by peripheral blood mononuclear cells (PBMCs) [71]. This modulation in immunological activities of PBMCs is critical in preventing the viscious cycle of excessive inflammations in COVID-19 (Fig. 1), hence, reducing the risk of excessive pro-thrombotic cytokine release and hypercoagulable state (Fig. 2). Despite the negative regulating effects on pro-inflammatory cytokine productions, chloroquine and hydroxychloroquine are less associated with secondary infections following their treatment than immuno-suppressive medications are, as their effects on the immune system is immuno-modulatory [72]. In addition, hydroxychloroquine reduces the risk of vascular thrombosis by inhibiting platelet activation in response to pro-coagulant factors, as evidenced by the in vitro study showing that hydroxychloroquine, at the concentration of $1 \mathrm{mM}$, abrogates expressions of platelet CD41a and CD61, which indicate platelet activation, following aPL and thrombin agonist receptor peptide treatment. This inhibitory effect of hydroxychloroquine on platelet activation is also present even when the concentration of hydroxychloroquine is as low as $0.0125 \mathrm{mM}$ [73]. Similar function in the inhibition of platelet activation has also been demonstrated in vitro with chloroquine [74]. In agreement with its function of platelet inhibition, hydroxychloroquine can reduce the incidence of vascular thrombotic events after operations or in autoimmune diseases including systemic lupus erythematosus (SLE) and APS [75, 76]. Furthermore, In vitro evidence has shown that chloroquine prevents SARS-CoV-2 infection in Vero E6 cells by preventing cell entry and interfering with the process of virus-cell fusion [77]. Chloroquine can interfere with host cell-entry of SARS-CoV-2 by preventing the terminal glycosylation of its receptor ACE2 [72]. Therefore, chloroquine and hydroxychloroquine can theoretically lower the risk of hypercoagulable state and vascular thrombosis by alleviating the endothelitis caused by direct SARS-CoV-2 invasion into the host vascular ECs in COVID-19 [31].

\section{Potential ACE2 down-regulation in COVID-19 can contribute to hypercoagulable state in conjunction with excessive cytokine Release}

\section{Evidence predicting ACE2 down-regulation in COVID-19}

SARS-CoV-2 and SARS-CoV bind to ACE2 for cell entry, and share a similar amino acid sequence in their receptor-binding spike proteins, with a $76 \%$ amino acid sequence similarity between the spike protein of SARSCoV-2 and that of SARS-CoV S Urbani [78, 79]. These two viruses also bind to the same receptor, ACE2, for cell entry [78]. As in the case of SARS-CoV infection, the SARS$\mathrm{CoV}-2$ spike protein is primed by the transmembrane serine protease 2 (TMPRSS2), which facilitates viral entry into host cells [80]. A recent study using single-cell RNA-sequencing (scRNA-seq) has identified cells with co-expressions of ACE2 and TMPRSS2, including type II pneumocytes, ileal enterocytes, and nasal goblet cells [81]. These cells are, therefore, targets for SARS-CoV-2 invasion in the host.

Interactome model for interactions between SARS-CoV-2 and human cell, based on characteristics of human protein/ SARS-CoV and human protein/MERS-CoV interactions, predicts a down-regulating effect of SARS-CoV-2 infection on ACE2 expression in human cells [7]. ACE2 protein expression is found in multiple organs and tissues, including vascular ECs and SMCs [82]. Both in vitro and in vivo experiments have pointed out the role of SARS-CoV spike protein in down-regulating ACE2 expression through ACE2 binding [83]. SARS-CoV infection can result in a reduction in myocardial ACE2 expression at mRNA and protein levels in mice [84]. In vitro experiments have proved the ability of SARS-CoV spike protein to induce the activity of a disintegrin and metalloprotease (ADAM17), which sheds ACE2 from the membrane, down-regulating the expression of ACE2 in Vero E6 cells [85]. Although TMPRSS2 may interfere with the ACE2 shedding activity of ADAM17, coexpressions of TMPRSS2 and ACE2 can only be found in restricted types of cells, as indicated by the result of the recent scRNA-seq experiment $[81,86]$. Due to the similarity between amino acid sequences of SARS-CoV and SARSCoV-2 spike proteins, SARS-CoV-2 could lead to a downregulation in ACE2 expression in COVID-19 through ACE2 binding. However, further experiments using animal models with SARS-CoV-2 infection are still required to better clarify the effect of SARS-CoV-2 infection on ACE2 expression in different tissues or cell types.

\section{Pro-inflammatory and pro-thrombotic mechanisms of ACE2 down-regulation}

Ang II (Angiotensin II) is the effector molecule in the ACE/ Ang II/AT1 receptor (angiotensin II receptor type 1) axis, associated with pro-thrombotic activities including increased TF and PAI-1 production by aortic ECs and SMCs [87, 88]. Upon binding to AT1R, Ang II can induce ROS production by stimulating the activity of NADH and NADPH oxidases in vascular SMCs, promoting oxidative stress and vascular inflammation, which can lead to vascular injury and thrombus formation [89]. 
Many pieces of experimental evidence have suggested the anti-thrombotic activity of the ACE2/Ang 1-7 (Angiotensin 1-7)/Mas receptor axis. In rats, low ACE2 activity is related to thrombus formation, whereas enhancing ACE2 activity decreases both platelet accumulation and size of thrombi, delaying the thrombosis [90]. ACE2 catalyzes Ang II to Ang 1-7, which does not have the pro-thrombotic functions associated with Ang II [91], preventing the adverse effect of Ang II on vascular injury and thrombosis [92]. Furthermore, Ang 1-7 can promote platelet NO release by binding to the Mas receptor on the platelet [93].

Therefore, ACE2 down-regulation, which possibly occurs in COVID-19, enhances the activation of the ACE/ Ang II/AT1 receptor axis. In addition to the pro-thrombotic activities of the ACE/Ang II/AT1 receptor axis, enhanced Ang II level can further inhibit the expression of ACE2 by activating mitogen-activated protein kinase 1 (MAPK1) and MAPK3, worsening the vascular injury and thrombosis [94].

\section{Mutually promoting effects between ACE2 down-regulation and excessive cytokine release on their pro-thrombotic activities}

Excessive cytokine release in severe COVID-19 can be a crucial factor contributing to the pro-thrombotic activities related to ACE2 down-regulation (Fig. 3). Emerging amounts of evidence have shown the critical role of pro-inflammatory cytokines in Ang II-mediated vascular

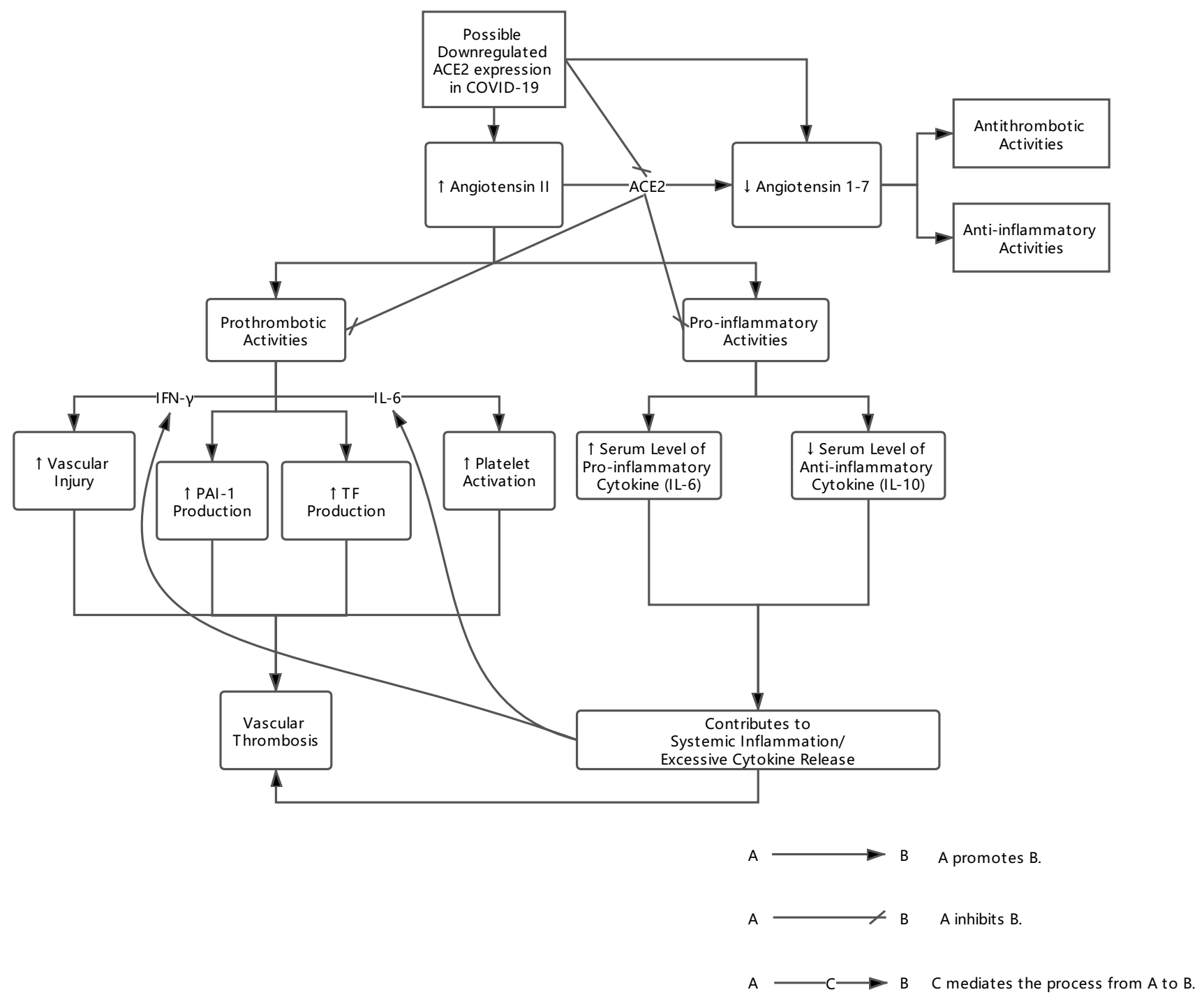

Fig. 3 Schematic diagram showing the mechanisms by which potential ACE2 expression down-regulation in COVID-19 contributes to vascular thrombosis and the reciprocal promoting relationship between the effect of ACE2 expression down-regulation and that of excessive cytokine release on vascular thrombosis. ACE2 angiotensin-converting enzyme $2, I F N-\gamma$ interferon $\gamma, I L-6$ interleukin-6, PAI1 plasminogen activator inhibitor- $1, T F$ tissue factor 
dysfunctions. In IFN- $\gamma$ knockout mice, characteristics of Ang II-mediated vascular injury are attenuated. This attenuation of vascular injury is due to decreased IFN- $\gamma$ mediated nature killer (NK) cell and monocyte recruitment, and reduced mutual activation of NK cells and monocytes at the vessel [95]. In addition, a recent animal study suggests that Ang II promotes thrombosis through increased platelet activation induced by T cell-dependent IL- 6 signaling [96]. Hence, the elevated serum levels of pro-inflammatory cytokines in severe COVID-19 tend to favor the Ang IImediated vascular injury and thrombosis.

ACE2 down-regulation can, in turn, lead to enhanced levels of cytokines with pro-thrombotic activities (Fig. 3). A randomized double-blind clinical study has shown that in patients with coronary artery disease, ACEI/ARB treatment elevates the serum level of IL-10, but reduce the serum level of IL-6, thereby decreasing the thrombin stimulated platelet aggregation in the plasma [97]. Thus, in COVID-19, the possible down-regulated ACE2 activity can leave the activity of ACE/Ang II/AT1 axis uncontrolled, resulting in excessive inflammation characterized by increased serum levels of pro-thrombotic cytokines but decreased serum levels of antithrombotic cytokines, contributing to vascular thrombosis.

\section{ACEI/ARB treatment can reduce the risk of vascular thrombosis in hypertensive COVID-19 patients}

ACEI/ARB has been essential for treating hypertension and heart failure, but the use of ACEI/ARB during the COVID19 pandemic was concerned because of the potential risk of ACEI/ARB in enhancing ACE2 expression, which may increase the chance or severity of infection.

However, most of recent clinical studies do not indicate an association between ACEI/ARB treatment and a higher risk of SARS-CoV-2 infection. A meta-analysis on 19,000 cases of COVID-19 suggests that ACEI/ARB does not increase the risk of SARS-CoV-2 infection and the disease transition from mild to severe, and that ACEI/ARB treatment reduces the incidence of mortality compared to other anti-hypertensive agents in COVID-19 patients with hypertension [98]. Moreover, in a retrospective analysis of 1128 adult hypertensive COVID-19 patients, compared to patients not taking ACEI/ARB or taking other anti-hypertensive drugs, those taking ACEI/ARB are associated with a lower risk of DIC and mortality [99].

As described at the end of the previous section, ACEI/ ARB can lower the risk of hypercoagulability by controlling systemic inflammations. Besides, ACEI/ARB can also reduce vascular inflammations, preventing vascular injuries and platelet activations (Fig. 3) [97]. ACEI can prevent vascular inflammation by reducing the activity of nuclear factor kappa-B (NF- $\mathrm{KB})$ in vascular cells and macrophages [100, 101]. Furthermore, ACEI reduces levels of pro-inflammatory cytokine expressions in the aorta in patients with abdominal aortic aneurysm, indicating the ability of ACEI to reduce vascular inflammation [102]. Additionally, ARB can normalize the vascular inflammation and vascular dysfunction caused by Ang II [103]. Antagonization of AT1 by ARB can result in increased Ang II-induced EC AT2 activation, which can promote NO production, preventing vascular thrombosis [104, 105]. Hence, hypertensive COVID-19 patients can benefit from the vasoprotective mechanisms of ACEI/ARB. Better clinical outcomes of hypertensive COVID-19 patients who received ACEI/ARB in recent clinical studies can be in part attributed to the capability of ACEI/ARB to prevent a hypercoagulable state.

\section{Conclusion}

The severity of COVID-19 is associated with both excessive cytokine release and hypercoagulable state. Age and HLA polymorphisms could be factors that determine the propensity to develop the over-activated inflammations in COVID-19. In severe COVID-19 patients, the excessive release of pro-inflammatory cytokines, including IL-2, IFN$\gamma$, and IL-6, has been consistently shown in recent retrospective clinical studies. Abundant pieces of evidence have indicated the role of these pro-inflammatory cytokines in promoting a hypercoagulable state and, therefore, vascular thrombosis. However, excessive pro-inflammatory cytokine release might not be the only etiology of hypercoagulable state in COVID-19, and its significance in the pathogenesis of hypercoagulable state in severe COVID-19 should be investigated in future studies.

Because of structural similarities between receptor binding proteins of SARS-CoV and SARS-CoV-2, SARS-CoV-2 infection is likely to result in ACE2 down-regulation, which has been confirmed in SARS-CoV infection previously. This hypothesis is currently supported by the prediction using an interactome model, but further experimental studies are needed to confirm the hypothesis. ACE2 down-regulation can lead to Ang II-mediated vascular dysfunction and thrombosis. Furthermore, ACE2 down-regulation and excessive pro-inflammatory cytokine release can mutually promote the pro-thrombotic activities of each other.

Understanding the mechanisms behind the vascular thrombotic events in severe patients with COVID-19 is essential for the prevention and treatment of vascular thrombosis in COVID-19. ACEI/ARB can prevent hypercoagulable state by activating ACE2/Ang 1-7 /Mas receptor axis while inhibiting ACE/Ang II/AT1 receptor axis, which possibly explains the reduced incidence of DIC in hypertensive COVID-19 patients receiving ACEI/ARB treatment. Anti-inflammatory medications, including tocilizumab, chloroquine, and hydroxychloroquine, could be 
an effective treatment to control the over-activated inflammatory response and have the potential to reduce the risk of vascular thrombosis in severe COVID-19. The potential of these anti-inflammatory medications to reduce vascular thrombotic events, along with the optimum choice of an anti-inflammatory drug to control the excessive cytokine release, detailed standards for patient selection, as well as the optimal time of initiation and the optimal duration of the anti-inflammatory therapy, are remained to be elucidated in future clinical studies.

Author contributions All authors contributed equally to the preparation of this manuscript.

Funding This work was supported by Beijing Natural Science Foundation [7182131]; Chinese Academy of Medical Sciences Innovation Fund for Medical Sciences [2018-I2M-AI-004]; Non-profit Central Research Institute Fund of Chinese Academy of Medical Sciences [2019XK320004]; Peking Union Medical College Hospital Science Fund of Key Projects for Junior Faculty [PUMCH-2016-1.20]; and Beijing Municipal Science and Technology Commission "clinical application of capital characteristics" [Z161100000516093].

\section{Compliance with ethical standards}

Conflict of interest There is no conflict of interest involved in the article.

Informed consent Consents in written form were obtained from all participants. All authors have read the manuscript and approved the manuscript for publication.

\section{References}

1. Tang N, Li D, Wang X, Sun Z (2020) Abnormal coagulation parameters are associated with poor prognosis in patients with novel coronavirus pneumonia. J Thrombos Haemost 18(4):844847. https://doi.org/10.1111/jth.14768

2. Huang C, Wang Y, Li X, Ren L, Zhao J, Hu Y, Zhang L, Fan G, Xu J, Gu X, Cheng Z, Yu T, Xia J, Wei Y, Wu W, Xie X, Yin W, Li H, Liu M, Xiao Y, Gao H, Guo L, Xie J, Wang G, Jiang R, Gao Z, Jin Q, Wang J, Cao B (2020) Clinical features of patients infected with 2019 novel coronavirus in Wuhan, China. Lancet 395(10223):497-506. https://doi.org/10.1016/S0140 $-6736(20) 30183-5$

3. Wan S, Yi Q, Fan S, Lv J, Zhang X, Guo L, Lang C, Xiao Q, Xiao K, Yi Z, Qiang M, Xiang J, Zhang B, Chen Y (2020) Characteristics of lymphocyte subsets and cytokines in peripheral blood of 123 hospitalized patients with 2019 novel coronavirus pneumonia (NCP). medRxiv. https://doi.org/10.1101/2020.02.10.20021 832

4. Yang Y, Shen C, Li J, Yuan J, Yang M, Wang F, Li G, Li Y, Xing L, Peng L, Wei J, Cao M, Zheng H, Wu W, Zou R, Li D, Xu Z, Wang H, Zhang M, Zhang Z, Liu L, Liu Y (2020) Exuberant elevation of IP-10, MCP-3 and IL-1ra during SARS-CoV-2 infection is associated with disease severity and fatal outcome. medRxiv. https://doi.org/10.1101/2020.03.02.20029975
5. Liu J, Li S, Liu J, Liang B, Wang X, Wang H, Li W, Tong Q, Yi J, Zhao L, Xiong L, Guo C, Tian J, Luo J, Yao J, Pang R, Shen H, Peng C, Liu T, Zhang Q, Wu J, Xu L, Lu S, Wang B, Weng Z, Han C, Zhu H, Zhou R, Zhou H, Chen X, Ye P, Zhu B, He S, He Y, Jie S, Wei P, Zhang J, Lu Y, Wang W, Zhang L, Li L, Zhou F, Wang J, Dittmer U, Lu M, Hu Y, Yang D, Zheng X (2020) Longitudinal characteristics of lymphocyte responses and cytokine profiles in the peripheral blood of SARS-CoV-2 infected patients. medRxiv. https://doi.org/10.1101/2020.02.16.20023671

6. Zhou Y, Fu B, Zheng X, Wang D, Zhao C, Qi Y, Sun R, Tian Z, Xu X, Wei H (2020) Aberrant pathogenic GM-CSF+ T cells and inflammatory CD14+CD16+ monocytes in severe pulmonary syndrome patients of a new coronavirus. bioRxiv. https://doi. org/10.1101/2020.02.12.945576

7. Guzzi PH, Mercatelli D, Ceraolo C, Giorgi FM (2020) Master regulator analysis of the SARS-CoV-2/human interactome. J Clin Med. https://doi.org/10.3390/jcm9040982

8. Guan WJ, Ni ZY, Hu Y, Liang WH, Ou CQ, He JX, Liu L, Shan H, Lei CL, Hui DSC, Du B, Li LJ, Zeng G, Yuen KY, Chen RC, Tang CL, Wang T, Chen PY, Xiang J, Li SY, Wang JL, Liang ZJ, Peng YX, Wei L, Liu Y, Hu YH, Peng P, Wang JM, Liu JY, Chen Z, Li G, Zheng ZJ, Qiu SQ, Luo J, Ye CJ, Zhu SY, Zhong NS, China Medical Treatment Expert Group for C (2020) Clinical characteristics of coronavirus disease 2019 in China. N Engl J Med. https://doi.org/10.1056/NEJMoa2002032

9. Lippi G, Favaloro EJ (2020) D-dimer is associated with severity of coronavirus disease 2019: a pooled analysis. Thromb Haemost (EFirst). https://doi.org/10.1055/s-0040-1709650

10. Zhang Y, Xiao M, Zhang S, Xia P, Cao W, Jiang W, Chen H, Ding X, Zhao H, Zhang H, Wang C, Zhao J, Sun X, Tian R, Wu W, Wu D, Ma J, Chen Y, Zhang D, Xie J, Yan X, Zhou X, Liu Z, Wang J, Du B, Qin Y, Gao P, Qin X, Xu Y, Zhang W, Li T, Zhang F, Zhao Y, Li Y, Zhang S (2020) Coagulopathy and antiphospholipid antibodies in patients with Covid-19. N Engl J Med 120:876. https://doi.org/10.1056/NEJMc2007575

11. Galrão L, Brites C, Atta ML, Atta A, Lima I, Gonzalez F, Magalhães F, Santiago M (2007) Antiphospholipid antibodies in HIV-positive patients. Clin Rheumatol 26(11):1825. https:// doi.org/10.1007/s10067-007-0581-6

12. Shoenfeld Y, Blank M, Cervera R, Font J, Raschi E, Meroni P-L (2006) Infectious origin of the antiphospholipid syndrome. Ann Rheumat Dis 65(1):2-6. https://doi.org/10.1136/ard.2005.04544 3

13. Qin C, Zhou L, Hu Z, Zhang S, Yang S, Tao Y, Xie C, Ma K, Shang K, Wang W, Tian D-S (2020) Dysregulation of immune response in patients with COVID-19 in Wuhan, China. Clin Infect Dis. https://doi.org/10.1093/cid/ciaa248

14. Wang F, Nie J, Wang H, Zhao Q, Xiong Y, Deng L, Song S, Ma Z, Mo P, Zhang Y (2020) Characteristics of peripheral lymphocyte subset alteration in COVID-19 pneumonia. J Infect Dis. https://doi.org/10.1093/infdis/jiaa150

15. Goyal P, Choi JJ, Pinheiro LC, Schenck EJ, Chen R, Jabri A, Satlin MJ, Campion TR Jr, Nahid M, Ringel JB, Hoffman KL, Alshak MN, Li HA, Wehmeyer GT, Rajan M, Reshetnyak E, Hupert N, Horn EM, Martinez FJ, Gulick RM, Safford MM (2020) Clinical characteristics of Covid-19 in New York city. N Engl J Med. https://doi.org/10.1056/NEJMc2010419

16. Channappanavar R, Fehr AR, Zheng J, Wohlford-Lenane C, Abrahante JE, Mack M, Sompallae R, McCray PB Jr, Meyerholz DK, Perlman S (2019) IFN-I response timing relative to virus replication determines MERS coronavirus infection outcomes. J Clin Investig 129(9):3625-3639. https://doi.org/10.1172/JCI12 6363

17. Channappanavar R, Fehr Anthony R, Vijay R, Mack M, Zhao J, Meyerholz David K, Perlman S (2016) Dysregulated type I interferon and inflammatory monocyte-macrophage responses 
cause lethal pneumonia in SARS-CoV-infected mice. Cell Host Microbe 19(2):181-193. https://doi.org/10.1016/j. chom.2016.01.007

18. Becher B, Tugues S, Greter M (2016) GM-CSF: from growth factor to central mediator of tissue inflammation. Immunity 45(5):963-973. https://doi.org/10.1016/j.immuni.2016.10.026

19. Na YR, Jung D, Gu GJ, Seok SH (2016) GM-CSF grown bone marrow derived cells are composed of phenotypically different dendritic cells and macrophages. Mol Cells 39(10):734-741. https://doi.org/10.14348/molcells.2016.0160

20. Shibata Y, Berclaz P-Y, Chroneos ZC, Yoshida M, Whitsett JA, Trapnell BC (2001) GM-CSF regulates alveolar macrophage differentiation and innate immunity in the lung through PU.1. Immunity 15(4):557-567. https://doi.org/10.1016/S1074 -7613(01)00218-7

21. Uchida K, Beck DC, Yamamoto T, Berclaz P-Y, Abe S, Staudt MK, Carey BC, Filippi M-D, Wert SE, Denson LA, Puchalski JT, Hauck DM, Trapnell BC (2007) GM-CSF autoantibodies and neutrophil dysfunction in pulmonary alveolar proteinosis. N Engl J Med 356(6):567-579. https://doi.org/10.1056/NEJMoa062505

22. Slifka MK, Whitmire JK, Ahmed R (1997) Bone marrow contains virus-specific cytotoxic T lymphocytes. Blood 90(5):2103-2108

23. de Bruin AM, Buitenhuis M, van der Sluijs KF, van Gisbergen KP, Boon L, Nolte MA (2010) Eosinophil differentiation in the bone marrow is inhibited by T cell-derived IFN-gamma. Blood 116(14):2559-2569. https://doi.org/10.1182/blood-2009-12261339

24. de Bruin AM, Libregts SF, Valkhof M, Boon L, Touw IP, Nolte MA (2012) IFN $\gamma$ induces monopoiesis and inhibits neutrophil development during inflammation. Blood 119(6):1543-1554. https://doi.org/10.1182/blood-2011-07-367706

25. Schurch CM, Riether C, Ochsenbein AF (2014) Cytotoxic $\mathrm{CD} 8+\mathrm{T}$ cells stimulate hematopoietic progenitors by promoting cytokine release from bone marrow mesenchymal stromal cells. Cell Stem Cell 14(4):460-472. https://doi.org/10.1016/j. stem.2014.01.002

26. Wongchana W, Palaga T (2012) Direct regulation of interleukin-6 expression by Notch signaling in macrophages. Cell Mol Immunol 9(2):155-162. https://doi.org/10.1038/cmi.2011.36

27. Montecino-Rodriguez E, Berent-Maoz B, Dorshkind K (2013) Causes, consequences, and reversal of immune system aging. J Clin Investig 123(3):958-965. https://doi.org/10.1172/JCI64096

28. Darrigues J, van Meerwijk JPM, Romagnoli P (2018) Agedependent changes in regulatory $\mathrm{T}$ lymphocyte development and function: a mini-review. Gerontology 64(1):28-35. https://doi. org/10.1159/000478044

29. Dutta M, Dutta P, Medhi S, Borkakoty B, Biswas D (2018) Polymorphism of HLA class I and class II alleles in influenza A(H1N1)pdm09 virus infected population of Assam, Northeast India. J Med Virol 90(5):854-860. https://doi.org/10.1002/ jmv. 25018

30. José RJ, Williams AE, Chambers RC (2014) Proteinase-activated receptors in fibroproliferative lung disease. Thorax 69(2):190 192. https://doi.org/10.1136/thoraxjnl-2013-204367

31. Varga Z, Flammer AJ, Steiger P, Haberecker M, Andermatt R, Zinkernagel AS, Mehra MR, Schuepbach RA, Ruschitzka F, Moch H (2020) Endothelial cell infection and endotheliitis in COVID-19. Lancet 395(10234):1417-1418. https://doi. org/10.1016/S0140-6736(20)30937-5

32. Liao W, Lin J-X, Wang L, Li P, Leonard WJ (2011) Modulation of cytokine receptors by IL-2 broadly regulates differentiation into helper T cell lineages. Nat Immunol 12(6):551-559. https:// doi.org/10.1038/ni.2030

33. Liao W, Schones DE, Oh J, Cui Y, Cui K, Roh T-Y, Zhao K, Leonard WJ (2008) Priming for T helper type 2 differentiation by interleukin 2-mediated induction of interleukin 4 receptor alpha-chain expression. Nat Immunol 9(11):1288-1296. https:// doi.org/10.1038/ni.1656

34. Chinen T, Kannan AK, Levine AG, Fan X, Klein U, Zheng Y, Gasteiger G, Feng Y, Fontenot JD, Rudensky AY (2016) An essential role for the IL-2 receptor in T(reg) cell function. Nat Immunol 17(11):1322-1333. https://doi.org/10.1038/ni.3540

35. Josefowicz SZ, Lu L-F, Rudensky AY (2012) Regulatory T cells: mechanisms of differentiation and function. Annu Rev Immunol 30:531-564. https://doi.org/10.1146/annurev.immunol.25.02210 6.141623

36. Takahashi K, Uwabe Y, Sawasaki Y, Kiguchi T, Nakamura H, Kashiwabara K, Yagyu H, Matsuoka T (1998) Increased secretion of urokinase-type plasminogen activator by human lung microvascular endothelial cells. Am J Physiol 275(1):L47-L54. https://doi.org/10.1152/ajplung.1998.275.1.L47

37. Baars JW, de Boer JP, Wagstaff J, Roem D, Eerenberg-Belmer AJ, Nauta J, Pinedo HM, Hack CE (1992) Interleukin-2 induces activation of coagulation and fibrinolysis: resemblance to the changes seen during experimental endotoxaemia. Br J Haematol 82(2):295-301. https://doi.org/10.1111/j.1365-2141.1992.tb064 21.x

38. Kasahara T, Hooks JJ, Dougherty SF, Oppenheim JJ (1983) Interleukin 2-mediated immune interferon (IFN-gamma) production by human $\mathrm{T}$ cells and $\mathrm{T}$ cell subsets. J Immunol 130(4):1784-1789

39. Todoroki N, Watanabe Y, Akaike T, Katagiri Y, Tanoue K, Yamazaki H, Tsuji T, Toyoshima S, Osawa T (1991) Enhancement by IL- $1 \beta$ and IFN- $\gamma$ of platelet activation: adhesion to leukocytes via GMP-140/padgem protein (CD62). Biochem Biophys Res Commun 179(2):756-761. https://doi.org/10.1016/0006291X(91)91881-C

40. Del Prete G, De Carli M, Lammel RM, D'Elios MM, Daniel KC, Giusti B, Abbate R, Romagnani S (1995) Th1 and Th2 T-helper cells exert opposite regulatory effects on procoagulant activity and tissue factor production by human monocytes. Blood 86(1):250-257

41. Kossmann S, Schwenk M, Hausding M, Karbach SH, Schmidgen MI, Brandt M, Knorr M, Hu H, Kröller-Schön S, Schönfelder T, Grabbe S, Oelze M, Daiber A, Münzel T, Becker C, Wenzel P (2013) Angiotensin II-induced vascular dysfunction depends on interferon- $\gamma$ - driven immune cell recruitment and mutual activation of monocytes and NK-cells. Arterioscler Thrombos Vasc Biol 33(6):1313-1319. https://doi.org/10.1161/ATVBA HA.113.301437

42. De Caterina R, Libby P, Peng HB, Thannickal VJ, Rajavashisth TB, Gimbrone MA, Shin WS, Liao JK (1995) Nitric oxide decreases cytokine-induced endothelial activation. Nitric oxide selectively reduces endothelial expression of adhesion molecules and proinflammatory cytokines. J Clin Investig 96(1):60-68. https://doi.org/10.1172/JCI118074

43. Zhang H, Potter BJ, Cao J-M, Zhang C (2011) Interferon-gamma induced adipose tissue inflammation is linked to endothelial dysfunction in type 2 diabetic mice. Basic Res Cardiol 106(6):11351145. https://doi.org/10.1007/s00395-011-0212-x

44. Dorsam RT, Kunapuli SP (2004) Central role of the P2Y12 receptor in platelet activation. J Clin Investig 113(3):340-345. https://doi.org/10.1172/JCI20986

45. Coenen DM, Mastenbroek TG, Cosemans JMEM (2017) Platelet interaction with activated endothelium: mechanistic insights from microfluidics. Blood 130(26):2819-2828. https://doi. org/10.1182/blood-2017-04-780825

46. Bertin F-R, Rys RN, Mathieu C, Laurance S, Lemarié CA, Blostein MD (2019) Natural killer cells induce neutrophil extracellular trap formation in venous thrombosis. J Thrombos Haemost 17(2):403-414. https://doi.org/10.1111/jth.14339 
47. Nosaka M, Ishida Y, Kimura A, Kuninaka Y, Inui M, Mukaida N, Kondo T (2011) Absence of IFN- $\gamma$ accelerates thrombus resolution through enhanced MMP-9 and VEGF expression in mice. J Clin Investig 121(7):2911-2920. https://doi. org/10.1172/JCI40782

48. Bester J, Pretorius E (2016) Effects of IL-1 $\beta$, IL-6 and IL-8 on erythrocytes, platelets and clot viscoelasticity. Sci Rep 6:32188-32188. https://doi.org/10.1038/srep32188

49. Kaser A, Brandacher G, Steurer W, Kaser S, Offner FA, Zoller H, Theurl I, Widder W, Molnar C, Ludwiczek O, Atkins MB, Mier JW, Tilg H (2001) Interleukin-6 stimulates thrombopoiesis through thrombopoietin: role in inflammatory thrombocytosis. Blood 98(9):2720-2725. https://doi.org/10.1182/blood .V98.9.2720

50. Gao H, Zhang Q, Chen J, Cooper DKC, Hara H, Chen P, Wei L, Zhao Y, Xu J, Li Z, Cai Z, Luan S, Mou L (2018) Porcine IL-6, IL- $1 \beta$, and TNF- $\alpha$ regulate the expression of pro-inflammatory-related genes and tissue factor in human umbilical vein endothelial cells. Xenotransplantation 25(5):e12408. https:// doi.org/10.1111/xen.12408

51. Neumann F-J, Ott I, Marx N, Luther T, Kenngott S, Gawaz M, Kotzsch M, Schömig A (1997) Effect of human recombinant interleukin-6 and interleukin-8 on monocyte procoagulant activity. Arterioscler Thrombos Vasc Biol 17(12):3399-3405. https://doi.org/10.1161/01.ATV.17.12.3399

52. van der Poll T, Levi M, Hack CE, ten Cate H, van Deventer SJ, Eerenberg AJ, de Groot ER, Jansen J, Gallati H, Buller HR et al (1994) Elimination of interleukin 6 attenuates coagulation activation in experimental endotoxemia in chimpanzees. J Exp Med 179(4):1253-1259. https://doi.org/10.1084/ jem.179.4.1253

53. Burstein SA, Peng J, Friese P, Wolf RF, Harrison P, Downs T, Hamilton K, Comp P, Dale GL (1996) Cytokine-induced alteration of platelet and hemostatic function. Stem Cells 14(S1):154162. https://doi.org/10.1002/stem.5530140720

54. Romano M, Sironi M, Toniatti C, Polentarutti N, Fruscella P, Ghezzi P, Faggioni R, Luini W, van Hinsbergh V, Sozzani S, Bussolino F, Poli V, Ciliberto G, Mantovani A (1997) Role of IL-6 and its soluble receptor in induction of chemokines and leukocyte recruitment. Immunity 6(3):315-325. https://doi. org/10.1016/S1074-7613(00)80334-9

55. Barnes TC, Spiller DG, Anderson ME, Edwards SW, Moots RJ (2011) Endothelial activation and apoptosis mediated by neutrophil-dependent interleukin 6 trans-signalling: a novel target for systemic sclerosis? Ann Rheumat Dis 70(2):366-372. https://doi. org/10.1136/ard.2010.133587

56. Nosaka M, Ishida Y, Kimura A, Kuninaka Y, Taruya A, Ozaki M, Tanaka A, Mukaida N, Kondo T (2020) Crucial involvement of IL-6 in thrombus resolution in mice via macrophage recruitment and the induction of proteolytic enzymes. Front Immunol. https ://doi.org/10.3389/fimmu.2019.03150

57. Rega G, Kaun C, Weiss TW, Demyanets S, Zorn G, Kastl SP, Steiner S, Seidinger D, Kopp CW, Frey M, Roehle R, Maurer G, Huber K, Wojta J (2005) Inflammatory cytokines interleukin-6 and oncostatin $\mathrm{m}$ induce plasminogen activator inhibitor- 1 in human adipose tissue. Circulation 111(15):1938-1945. https:// doi.org/10.1161/01.Cir.0000161823.55935.Be

58. Rojas JM, Avia M, Martin V, Sevilla N (2017) IL-10: a multifunctional cytokine in viral infections. J Immunol Res 2017:6104054. https://doi.org/10.1155/2017/6104054

59. Demangel C, Bertolino P, Britton WJ (2002) Autocrine IL-10 impairs dendritic cell (DC)-derived immune responses to mycobacterial infection by suppressing DC trafficking to draining lymph nodes and local IL-12 production. Eur J Immunol 32(4):994-1002. https://doi.org/10.1002/1521-4141(20020 4)32:4<994:Aid-immu994>3.0.Co;2-6
60. Li X, Fang P, Sun Y, Shao Y, Yang WY, Jiang X, Wang H, Yang X (2020) Anti-inflammatory cytokines IL-35 and IL-10 block atherogenic lysophosphatidylcholine-induced, mitochondrial ROS-mediated innate immune activation, but spare innate immune memory signature in endothelial cells. Redox Biol 28:101373-101373. https://doi.org/10.1016/j.redox.2019.101373

61. Downing LJ, Strieter RM, Kadell AM, Wilke CA, Austin JC, Hare BD, Burdick MD, Greenfield LJ, Wakefield TW (1998) IL-10 regulates thrombus-induced vein wall inflammation and thrombosis. J Immunol 161(3):1471-1476

62. Sosman JA, Verma A, Moss S, Sorokin P, Blend M, Bradlow B, Chachlani N, Cutler D, Sabo R, Nelson M, Bruno E, Gustin D, Viana M, Hoffman R (2000) Interleukin 10-induced thrombocytopenia in normal healthy adult volunteers: evidence for decreased platelet production. Br J Haematol 111(1):104-111. https://doi.org/10.1046/j.1365-2141.2000.02314.x

63. Poredos P, Jezovnik MK (2011) In patients with idiopathic venous thrombosis, interleukin-10 is decreased and related to endothelial dysfunction. Heart Vessels 26(6):596-602. https:// doi.org/10.1007/s00380-010-0111-3

64. Shi Y, Wang Y, Shao C, Huang J, Gan J, Huang X, Bucci E, Piacentini M, Ippolito G, Melino G (2020) COVID-19 infection: the perspectives on immune responses. Cell Death Differ 27(5):1451-1454. https://doi.org/10.1038/s41418-020-0530-3

65. Liu Q, Zhou Y-h, Yang Z-q (2016) The cytokine storm of severe influenza and development of immunomodulatory therapy. Cell Mol Immunol 13(1):3-10. https://doi.org/10.1038/cmi.2015.74

66. Luo P, Liu Y, Qiu L, Liu X, Liu D, Li J (2020) Tocilizumab treatment in COVID-19: A single center experience. J Med Virol. https://doi.org/10.1002/jmv.25801

67. Xu X, Han M, Li T, Sun W, Wang D, Fu B, Zhou Y, Zheng X, Yang Y, Li X, Zhang X, Pan A, Wei H (2020) Effective treatment of severe COVID-19 patients with tocilizumab. Proc Natl Acad Sci USA 117(20):10970-10975. https://doi.org/10.1073/ pnas. 2005615117

68. Antwi-Amoabeng D, Kanji Z, Ford B, Beutler BD, Riddle MS, Siddiqui F (2020) Clinical outcomes in COVID-19 patients treated with tocilizumab: an individual patient data systematic review. J Med Virol. https://doi.org/10.1002/jmv.26038

69. Yu B, Li C, Chen P, Zhou N, Wang L, Li J, Jiang H, Wang DW (2020) Low dose of hydroxychloroquine reduces fatality of critically ill patients with COVID-19. Sci China Life Sci. https://doi. org/10.1007/s11427-020-1732-2

70. Borba MGS, Val FFA, Sampaio VS, Alexandre MAA, Melo GC, Brito M, Mourão MPG, Brito-Sousa JD, Baía-da-Silva D, Guerra MVF, Hajjar LA, Pinto RC, Balieiro AAS, Pacheco AGF, Santos JDO Jr, Naveca FG, Xavier MS, Siqueira AM, Schwarzbold A, Croda J, Nogueira ML, Romero GAS, Bassat Q, Fontes CJ, Albuquerque BC, Daniel-Ribeiro C-T, Monteiro WM, Lacerda MVG, Team ftC- (2020) Effect of high vs low doses of chloroquine diphosphate as adjunctive therapy for patients hospitalized with severe acute respiratory syndrome coronavirus 2 (SARSCoV-2) infection: a randomized clinical trial. JAMA Netw Open 3(4):e208857-e208857. https://doi.org/10.1001/jamanetwor kopen. 2020.8857

71. van den Borne BE, Dijkmans BA, de Rooij HH, le Cessie S, Verweij CL (1997) Chloroquine and hydroxychloroquine equally affect tumor necrosis factor-alpha, interleukin 6 , and interferongamma production by peripheral blood mononuclear cells. $\mathbf{J}$ Rheumatol 24(1):55-60

72. Ruiz-Irastorza G, Olivares N, Ruiz-Arruza I, Martinez-Berriotxoa A, Egurbide M-V, Aguirre C (2009) Predictors of major infections in systemic lupus erythematosus. Arthr Res Ther 11(4):R109. https://doi.org/10.1186/ar2764

73. Espinola RG, Pierangeli SS, Gharavi AE, Harris EN (2002) Hydroxychloroquine reverses platelet activation induced by 
human IgG antiphospholipid antibodies. Thromb Haemost 87(3):518-522

74. Janc̈inová V, Nosál R, Petriková M (1994) On the inhibitory effect of chloroquine on blood platelet aggregation. Thrombos Res 74(5):495-504. https://doi.org/10.1016/0049-3848(94)90270 $-4$

75. Carter AE, Eban R (1974) Prevention of postoperative deep venous thrombosis in legs by orally administered hydroxychloroquine sulphate. Br Med J 3(5923):94-95. https://doi.org/10.1136/ bmj.3.5923.94

76. Wang T-F, Lim W (2016) What is the role of hydroxychloroquine in reducing thrombotic risk in patients with antiphospholipid antibodies? Hematol Am Soc Hematol Educ Program 1:714-716. https://doi.org/10.1182/asheducation-2016.1.714

77. Wang M, Cao R, Zhang L, Yang X, Liu J, Xu M, Shi Z, Hu Z, Zhong W, Xiao G (2020) Remdesivir and chloroquine effectively inhibit the recently emerged novel coronavirus (2019-nCoV) in vitro. Cell Res 30(3):269-271. https://doi.org/10.1038/s4142 2-020-0282-0

78. Zhou P, Yang XL, Wang XG, Hu B, Zhang L, Zhang W, Si HR, Zhu Y, Li B, Huang CL, Chen HD, Chen J, Luo Y, Guo H, Jiang RD, Liu MQ, Chen Y, Shen XR, Wang X, Zheng XS, Zhao K, Chen QJ, Deng F, Liu LL, Yan B, Zhan FX, Wang YY, Xiao GF, Shi ZL (2020) A pneumonia outbreak associated with a new coronavirus of probable bat origin. Nature 579(7798):270-273. https://doi.org/10.1038/s41586-020-2012-7

79. Walls AC, Park Y-J, Tortorici MA, Wall A, McGuire AT, Veesler D (2020) Structure, function, and antigenicity of the SARSCoV-2 spike glycoprotein. Cell 181(2):281-292.e286. https:// doi.org/10.1016/j.cell.2020.02.058

80. Hoffmann M, Kleine-Weber H, Schroeder S, Krüger N, Herrler T, Erichsen S, Schiergens TS, Herrler G, Wu N-H, Nitsche A, Müller MA, Drosten C, Pöhlmann S (2020) SARS-CoV-2 Cell entry depends on ACE2 and TMPRSS2 and is blocked by a clinically proven protease inhibitor. Cell 181(2):271-280.e278. https ://doi.org/10.1016/j.cell.2020.02.052

81. Ziegler CGK, Allon SJ, Nyquist SK, Mbano IM, Miao VN, Tzouanas CN, Cao Y, Yousif AS, Bals J, Hauser BM, Feldman J, Muus C, Wadsworth MH II, Kazer SW, Hughes TK, Doran B, Gatter GJ, Vukovic M, Taliaferro F, Mead BE, Guo Z, Wang JP, Gras D, Plaisant M, Ansari M, Angelidis I, Adler H, Sucre JMS, Taylor CJ, Lin B, Waghray A, Mitsialis V, Dwyer DF, Buchheit KM, Boyce JA, Barrett NA, Laidlaw TM, Carroll SL, Colonna L, Tkachev V, Peterson CW, Yu A, Zheng HB, Gideon HP, Winchell CG, Lin PL, Bingle CD, Snapper SB, Kropski JA, Theis FJ, Schiller HB, Zaragosi L-E, Barbry P, Leslie A, Kiem H-P, Flynn JL, Fortune SM, Berger B, Finberg RW, Kean LS, Garber M, Schmidt AG, Lingwood D, Shalek AK, Ordovas-Montanes J (2020) SARS-CoV-2 receptor ACE2 is an interferon-stimulated gene in human airway epithelial cells and is detected in specific cell subsets across tissues. Cell. https://doi. org/10.1016/j.cell.2020.04.035

82. Hamming I, Timens W, Bulthuis MLC, Lely AT, Navis GJ, van Goor H (2004) Tissue distribution of ACE2 protein, the functional receptor for SARS coronavirus. A first step in understanding SARS pathogenesis. J Pathol 203(2):631-637. https://doi. org/10.1002/path. 1570

83. Kuba K, Imai Y, Rao S, Gao H, Guo F, Guan B, Huan Y, Yang P, Zhang Y, Deng W, Bao L, Zhang B, Liu G, Wang Z, Chappell M, Liu Y, Zheng D, Leibbrandt A, Wada T, Slutsky AS, Liu D, Qin C, Jiang C, Penninger JM (2005) A crucial role of angiotensin converting enzyme 2 (ACE2) in SARS coronavirus-induced lung injury. Nat Med 11(8):875-879. https://doi.org/10.1038/nm1267

84. Oudit GY, Kassiri Z, Jiang C, Liu PP, Poutanen SM, Penninger JM, Butany J (2009) SARS-coronavirus modulation of myocardial ACE2 expression and inflammation in patients with
SARS. Eur J Clin Investig 39(7):618-625. https://doi.org/10. 1111/j.1365-2362.2009.02153.x

85. Haga S, Yamamoto N, Nakai-Murakami C, Osawa Y, Tokunaga K, Sata T, Yamamoto N, Sasazuki T, Ishizaka Y (2008) Modulation of TNF-alpha-converting enzyme by the spike protein of SARS-CoV and ACE2 induces TNF-alpha production and facilitates viral entry. Proc Natl Acad Sci USA 105(22):78097814. https://doi.org/10.1073/pnas.0711241105

86. Heurich A, Hofmann-Winkler H, Gierer S, Liepold T, Jahn O, Pohlmann S (2014) TMPRSS2 and ADAM17 cleave ACE2 differentially and only proteolysis by TMPRSS2 augments entry driven by the severe acute respiratory syndrome coronavirus spike protein. J Virol 88(2):1293-1307. https://doi. org/10.1128/jvi.02202-13

87. Leeuwen RTV, Kol A, Andreotti F, Kluft C, Maseri A, Sperti G (1994) Angiotensin II increases plasminogen activator inhibitor type 1 and tissue-type plasminogen activator messenger RNA in cultured rat aortic smooth muscle cells. Circulation 90(1):362-368. https://doi.org/10.1161/01.CIR.90.1.362

88. Nishimura H, Tsuji H, Masuda H, Nakagawa K, Nakahara Y, Kitamura H, Kasahara T, Sugano T, Yoshizumi M, Sawada S, Nakagawa M (1997) Angiotensin II increases plasminogen activator inhibitor-1 and tissue factor mRNA expression without changing that of tissue type plasminogen activator or tissue factor pathway inhibitor in cultured rat aortic endothelial cells. Thromb Haemost 77(6):1189-1195

89. Griendling KK, Minieri CA, Ollerenshaw JD, Alexander RW (1994) Angiotensin II stimulates NADH and NADPH oxidase activity in cultured vascular smooth muscle cells. Circul Res 74(6):1141-1148. https://doi.org/10.1161/01.res.74.6.1141

90. Fraga-Silva RA, Sorg BS, Wankhede M, Dedeugd C, Jun JY, Baker MB, Li Y, Castellano RK, Katovich MJ, Raizada MK, Ferreira AJ (2010) ACE2 activation promotes antithrombotic activity. Mol Med (Cambridge, Mass) 16(5-6):210-215. https ://doi.org/10.2119/molmed.2009.00160

91. Nishimura H, Tsuji H, Masuda H, Kasahara T, Yoshizumi M, Sugano T, Kimura S, Kawano H, Kunieda Y, Yano S, Nakagawa K, Kitamura H, Nakahara Y, Sawada S, Nakagawa M (1999) The effects of angiotensin metabolites on the regulation of coagulation and fibrinolysis in cultured rat aortic endothelial cells. Thromb Haemost 82(5):1516-1521

92. Ogunlade B, Guidry JJ, Lazartigues E, Filipeanu C (2019) ACE2 internalization and degradation is controlled by ubiquitin ligase NEDD4. FASEB J 33(1_supplement):714. https:// doi.org/10.1096/fasebj.2019.33.1_supplement.719.14

93. Fraga-Silva RA, Pinheiro SV, Goncalves AC, Alenina N, Bader M, Santos RA (2008) The antithrombotic effect of angiotensin-(1-7) involves mas-mediated NO release from platelets. Mol Med (Cambridge, Mass) 14(1-2):28-35. https://doi. org/10.2119/2007-00073.Fraga-Silva

94. Gallagher PE, Ferrario CM, Tallant EA (2008) MAP kinase/ phosphatase pathway mediates the regulation of ACE2 by angiotensin peptides. Am J Physiol 295(5):C1169-C1174. https:// doi.org/10.1152/ajpcell.00145.2008

95. Kossmann S, Schwenk M, Hausding M, Karbach SH, Schmidgen MI, Brandt M, Knorr M, Hu H, Kroller-Schon S, Schonfelder T, Grabbe S, Oelze M, Daiber A, Munzel T, Becker C, Wenzel P (2013) Angiotensin II-induced vascular dysfunction depends on interferon-gamma-driven immune cell recruitment and mutual activation of monocytes and NK-cells. Arterioscler Thromb Vasc Biol 33(6):1313-1319. https://doi.org/10.1161/ atvbaha.113.301437

96. Senchenkova EY, Russell J, Yildirim A, Granger DN, Gavins FNE (2019) Novel role of T cells and IL-6 (Interleukin-6) in angiotensin II-induced microvascular dysfunction. 
Hypertension (Dallas, Tex: 1979) 73(4):829-838. https://doi. org/10.1161/hypertensionaha.118.12286

97. Schieffer B, Bunte C, Witte J, Hoeper K, Boger RH, Schwedhelm E, Drexler H (2004) Comparative effects of AT1-antagonism and angiotensin-converting enzyme inhibition on markers of inflammation and platelet aggregation in patients with coronary artery disease. J Am Coll Cardiol 44(2):362-368. https://doi. org/10.1016/j.jacc.2004.03.065

98. Zhang X, Yu J, Pan L-Y, Jiang H-Y (2020) ACEI/ARB use and risk of infection or severity or mortality of COVID-19: a systematic review and meta-analysis. Pharmacol Res 158:104927104927. https://doi.org/10.1016/j.phrs.2020.104927

99. Zhang P, Zhu L, Cai J, Lei F, Qin JJ, Xie J, Liu YM, Zhao YC, Huang $X$, Lin L, Xia M, Chen MM, Cheng X, Zhang X, Guo D, Peng Y, Ji YX, Chen J, She ZG, Wang Y, Xu Q, Tan R, Wang H, Lin J, Luo P, Fu S, Cai H, Ye P, Xiao B, Mao W, Liu L, Yan Y, Liu M, Chen M, Zhang XJ, Wang X, Touyz RM, Xia J, Zhang BH, Huang X, Yuan Y, Rohit L, Liu PP, Li H (2020) Association of inpatient use of angiotensin-converting enzyme inhibitors and angiotensin II receptor blockers with mortality among patients with hypertension hospitalized with COVID-19. Circul Res 126(12):1671-1681. https://doi.org/10.1161/circresaha .120 .317134

100. Hernández-Presa MA, Bustos C, Ortego M, Tuñón J, Ortega L, Egido J (1998) ACE inhibitor quinapril reduces the arterial expression of NF-kappaB-dependent proinflammatory factors but not of collagen I in a rabbit model of atherosclerosis. Am J Pathol 153(6):1825-1837. https://doi.org/10.1016/s0002 $-9440(10) 65697-0$

101. Hernández-Presa M, Bustos C, Ortego M, Tuñon J, Renedo G, Ruiz-Ortega M, Egido J (1997) Angiotensin-converting enzyme inhibition prevents arterial nuclear factor-kappa B activation, monocyte chemoattractant protein-1 expression, and macrophage infiltration in a rabbit model of early accelerated atherosclerosis. Circulation 95(6):1532-1541. https://doi.org/10.1161/01. cir.95.6.1532

102. Kortekaas KE, Meijer CA, Hinnen JW, Dalman RL, Xu B, Hamming JF, Lindeman JH (2014) ACE inhibitors potently reduce vascular inflammation, results of an open proof-of-concept study in the abdominal aortic aneurysm. PLoS ONE 9(12):e111952e111952. https://doi.org/10.1371/journal.pone.0111952

103. Rajagopalan S, Kurz S, Münzel T, Tarpey M, Freeman BA, Griendling KK, Harrison DG (1996) Angiotensin II-mediated hypertension in the rat increases vascular superoxide production via membrane NADH/NADPH oxidase activation. Contribution to alterations of vasomotor tone. J Clin Investig 97(8):19161923. https://doi.org/10.1172/JCI118623

104. Maeso R, Navarro-Cid J, Muñoz-García R, Rodrigo E, Ruilope LM, Lahera V, Cachofeiro V (1996) Losartan reduces phenylephrine constrictor response in aortic rings from spontaneously hypertensive rats Role of nitric oxide and angiotensin II type 2 receptors. Hypertension (Dallas, Tex 1979) 28(6):967-972. https ://doi.org/10.1161/01.hyp.28.6.967

105. Wiemer G, Schölkens BA, Wagner A, Heitsch H, Linz W (1993) The possible role of angiotensin II subtype AT2 receptors in endothelial cells and isolated ischemic rat hearts. J Hyper Suppl 11(5):S234-235

Publisher's Note Springer Nature remains neutral with regard to jurisdictional claims in published maps and institutional affiliations. 